\title{
Simulation and Optimization of M-commerce Steel Logistics System Based on Arena
}

\author{
Xin LI \\ School of Management, \\ Wuhan University of Science and Technology, \\ Wuhan, China \\ e-mail: 353930944@qq.com
}

\author{
KaiLing PAN \\ School of Management, \\ Wuhan University of Science and Technology, \\ Wuhan, China \\ e-mail:pank10122@qq.com
}

\begin{abstract}
In this paper, it makes a systematic analysis of the M-commerce steel logistics system, especially comparing and researching based on the Arena simulation, build a more complete evaluate method and index system of the process of M-commerce. Using queuing theory to set parameters reasonably, and then analyzing and evaluating the simulation results systematically. Finally sum up the research production and give feasible schemes to optimize the process of $M$ commerce Steel Logistics System.
\end{abstract}

Keywords-component; steel logistics system; M-commerce; Arena simulation; feasible schemes

\section{INTRODUCTION}

In recent years, the current world economic situation is facing the complex changes, the global financial crisis showed a weak economic recovery, the grim situation of growth in emerging economies has been severely fallen, bulk commodity circulation market showed excess supply can not be resolved, industry level divide to two kinds of serious problems, the way of thinking of the Internet penetration show with circulation multiple features, the traditional market has closer links with the modern logistics industry . The era of pure-play e-commerce has passed, the next ten years, there is no e-commerce, online and offline logistics combined to create a true network model. In China, the steel industry is the original industry, it has been the basic to the national economy development for long time, and has given an active effect of support and impulse to the economy. But in the domestic iron steel company, material supply cannot meet the requirement of grouping management. The slack information and the behindhand management schema are the essential problems existing in material supply of enterprise, and must be resolved through information technology and advanced management schema and the most importantly, the overcapacity problem of Chinese steel industry is serious. how to improve the logistics service level and how to reduce the cost of logistics activities are the matter of cardinal significance, many academicians began to focus on the problems of the development and application of the mobile E-commerce steel logistics system, However, how to evaluate the advantages and disadvantages of the E-commerce steel logistics system is very important [1].
Steel logistics system is a complex operation system with nonlinear structure, it is difficult to establish a mathematical model of conventional quantitative analysis, Therefore, this paper, according to the process of $\mathrm{M}$ commerce, and presents an evaluation system which can accurately reflect the performance of steel logistics system, Using the Arena simulation software to realize the modeling and analysis of the representative M-commerce steel logistics System, the simulation results are analyzed and evaluated.

\section{THE SUMMARY OF SIMULATION BASED ON ARENA}

The Arena software is a simulation software for management system, which is based on the SIMAN simulation language [2]. it developed a new generation of visual general interactive integrated simulation environment, which solved the organic integration of computer simulation and visualization technology, which has the advantages of high level simulator and the flexibility of special simulation language. The model has a strong sense of hierarchy that can flexibly carry out simulation modeling at all levels of it. The concept of object-oriented modeling and structured based on the special simulation language flexibility and ease of use of the simulator well together, directly to build a simulation model of the actual business process, consistent with the habit of thinking of conventional hierarchical modeling. For large or complex models, hierarchical modeling is really important. [3] It can be used for simulations of discrete and continuous systems, for simulation in manufacturing, including supply chain management, logistics, storing and other processes. Arena simulation software ensures a high degree of flexibility, various facilities for models of any level of complexity [4].

\section{THE LOGIC SimUlation MODEL}

The software of Arena uses the event scheduling method, the basic idea is to analyze the real system with event point of view, through the definition of events and events for each of the states of the system, according to the time sequence to determine and implement the logical relationship about each event. The M-commerce steel logistics System is essentially a process of arrival, waiting, processing and based on the principle of the simulation of the discrete event system. [5] 


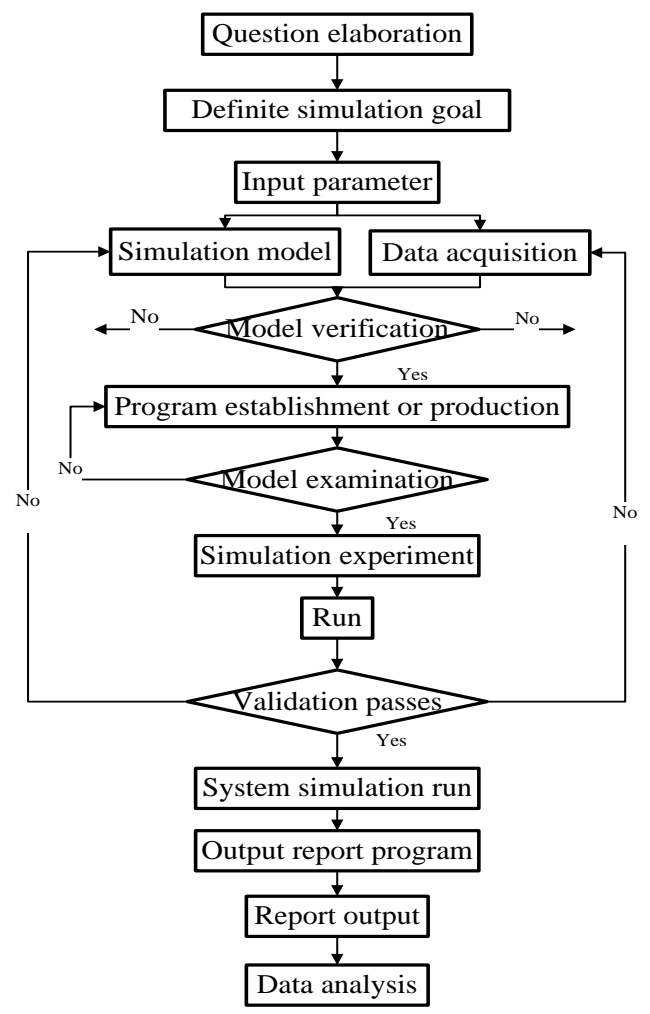

Figure 1. Basic flow chart of simulation

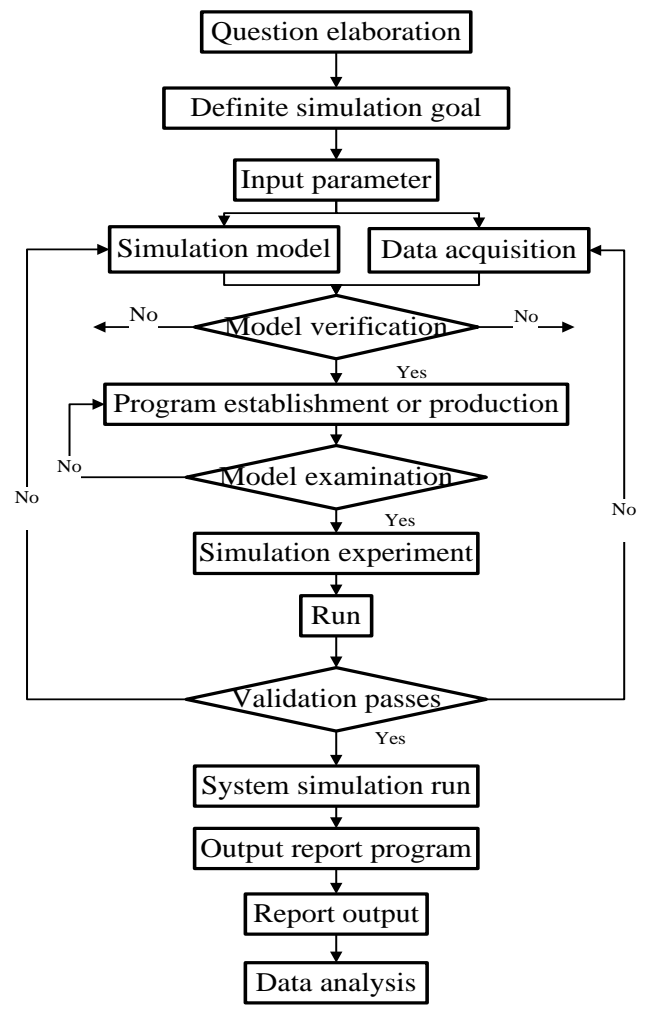

Figure 2. Input analyzer
In the MSLS(M-commerce Steel Logistics System), entities follow the rules of the mobile, they can entry network logistics system of steel trading and services for 24 hours a day it can make the upper reaches of the steel enterprises to the end users to form a unified customer request, processing center, logistics system and after-sales service of the integrated structure [6].

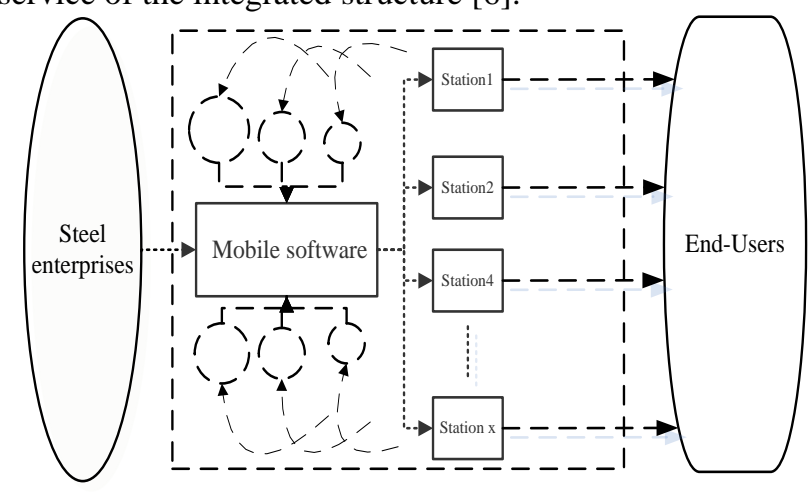

Figure 3. Basic flow chart of simulation

\section{Simulation Model AND PARAMETER SETting MODULE}

\section{A. Related Theories and Evaluation Indexes of the System}

The process of customer purchasing demand disposal to steel products follow the Frac ( M/ M/ S) Queuing System [7]

$\mathrm{M}$-Entity reach the system and follow the law of passion distribution process;

$\mathrm{N}-$ Service time follow the negative exponential distribution;

$\mathrm{S} \longrightarrow$ queuing rules of service counters follow the principle of first in first out.

Note: According to the formula, when the system is at stable state:

$$
\begin{aligned}
& p_{n}(s)=\left\{\begin{array}{l}
\frac{(s p)^{n} P_{0}(s)}{n !}, n \leq s \\
\frac{p^{n} s^{s}}{s !} P_{0}(s)=p^{n-s} p_{s}(s), n>s
\end{array}\right. \\
& p_{0}(s)=\frac{1}{\left[\sum_{n=0}^{s-1} \frac{(p s)^{n}}{n !}+\frac{(p s)^{s}}{s !}\left(\frac{1}{1-p}\right)\right]}
\end{aligned}
$$

$s-$ The number of the system servers;

$n-$ The number of the system customers;

$p_{n}(s) \longrightarrow$ The transient distribution of the queue length;

$\rho-$ Service intensity of the queuing system;

If definite $\rho<1$, system is in steady state conditions. 
Note: Using the methods of analytic calculation, several Measure indexes could be drawn from the results described above. The simulation used the following four commonly indicators of quality of service evaluation to measure the operation of the system, these four indicators are all generated by the simulation system.

$$
L_{q}=\sum_{k=s+1}^{\infty}(k-s) P_{n}(s)=\frac{(\rho s)^{s}}{(1-\rho)^{2} s !} p_{n}(s)
$$

$L_{q} \_$The average length of the queue;

$$
L_{s}=L_{q}+\rho s
$$

$L_{s} \ldots$ The average length of the team;

$$
W_{s}=\frac{L_{s}}{\lambda}
$$

$W_{s}$ The average sojourn time;

$$
W_{q}=\frac{L_{q}}{\lambda}
$$

$W_{q}$

According to the queuing theory to calculate method and the steady-state performance metric, make the reasonable assignment to the process of system, and evaluate the effectiveness of the operation result of the whole system, receiving station service efficiency, the server busy degree and the utilization rate of resources, in order to test and evaluate advantages and disadvantages of operational capabilities and the actual results[8].

\section{B. Simulation Model Design}

Assumptions:

(1)Building a perfectly systematic environment and checking that everything is still working;

(2)The process from the customers into the system to leave that means transaction is completed, it needn't consider the same customer repeatedly in and out the system;

(3)Do not consider operating loss and empty rate of system server;
(4)Do not consider order cost and price volatility of steel products.

The simulation model of the mode-MSLS:

The mode-MSLS is composed of the six submodels,follow the daily working hours of the working hours of e-commerce platform, all kinds of resources can be used 24 hours a day, set up the model seven days a week, and users can access system and apply requirements 24-hours a day.

\section{Simulation Data Input}

The simulation is in the process of M-commerce based on logic analysis and Arena simulation, the system level through the quantitative research data with different parameters under different parameters, the key factors to further explore the effect of the process of mobile ecommerce services, so as to optimize the design process,

\begin{tabular}{|c|c|c|c|}
\hline $\begin{array}{l}\text { Module } \\
\text { name }\end{array}$ & $\begin{array}{l}\text { Module } \\
\text { function }\end{array}$ & $\begin{array}{c}\text { Definitio } \\
\text { n of } \\
\text { function }\end{array}$ & Expression \\
\hline $\begin{array}{c}\text { Custom } \\
\text { er } \\
\text { arrive }\end{array}$ & $\begin{array}{l}\text { Law of entity } \\
\text { arrival time }\end{array}$ & $\begin{array}{l}\text { Exponent } \\
\text { ial }\end{array}$ & $\begin{array}{c}-0.001+\mathrm{EXPO} \\
(5)\end{array}$ \\
\hline $\begin{array}{c}\text { Arrival } \\
\text { time }\end{array}$ & $\begin{array}{c}\text { Customer } \\
\text { arrival time }\end{array}$ & $\begin{array}{c}\text { Triangula } \\
\mathrm{r}\end{array}$ & $\begin{array}{c}\text { TRIA } \\
(1.5,3.5,5.52)\end{array}$ \\
\hline $\begin{array}{l}\text { Choose } \\
\text { goods }\end{array}$ & Buying time & $\begin{array}{c}\text { Triangula } \\
\mathrm{r}\end{array}$ & $\begin{array}{c}\text { TRIA } \\
(0.5,1,1.5)\end{array}$ \\
\hline Pay & $\begin{array}{l}\text { Payment } \\
\text { time }\end{array}$ & Uniform & $\begin{array}{c}\text { UNIFORM } \\
(1,3,1.8)\end{array}$ \\
\hline $\begin{array}{l}\text { Confor } \\
\text { m order }\end{array}$ & $\begin{array}{c}\text { Confirmation } \\
\text { time }\end{array}$ & $\begin{array}{c}\text { Triangula } \\
\mathrm{r} \\
\end{array}$ & TRIA $(1,3,5)$ \\
\hline $\begin{array}{c}\text { Deliver } \\
\mathrm{y}\end{array}$ & $\begin{array}{c}\text { Logistics } \\
\text { delivery time }\end{array}$ & $\begin{array}{c}\text { Triangula } \\
\mathrm{r}\end{array}$ & TRIA $(2,4,6)$ \\
\hline $\begin{array}{l}\text { Repleni } \\
\text { sh }\end{array}$ & $\begin{array}{c}\text { Inventory } \\
\text { Transshipme } \\
\text { nt time }\end{array}$ & $\begin{array}{c}\text { Triangula } \\
\mathrm{r}\end{array}$ & TRIA $(1,3,5)$ \\
\hline $\begin{array}{c}\text { Handin } \\
\mathrm{g}\end{array}$ & $\begin{array}{c}\text { after-sales } \\
\text { service time }\end{array}$ & $\begin{array}{c}\text { Triangula } \\
\mathrm{r}\end{array}$ & TRIA $(1,3,5)$ \\
\hline
\end{tabular}
improve the service system performance.

TABLE I. Customer ARrival LAW AND THE PARAMETER AsSignMent OF SERVICE TIME OF MODE -MSLS

D. Analysis of the Results of the Simulation Output

We input the data into the Arena simulation software, it will automatically generate documents of txt and output all the statistics which set up in the model, it can get the results in the form of report, then sort and analyze those related statistics. 


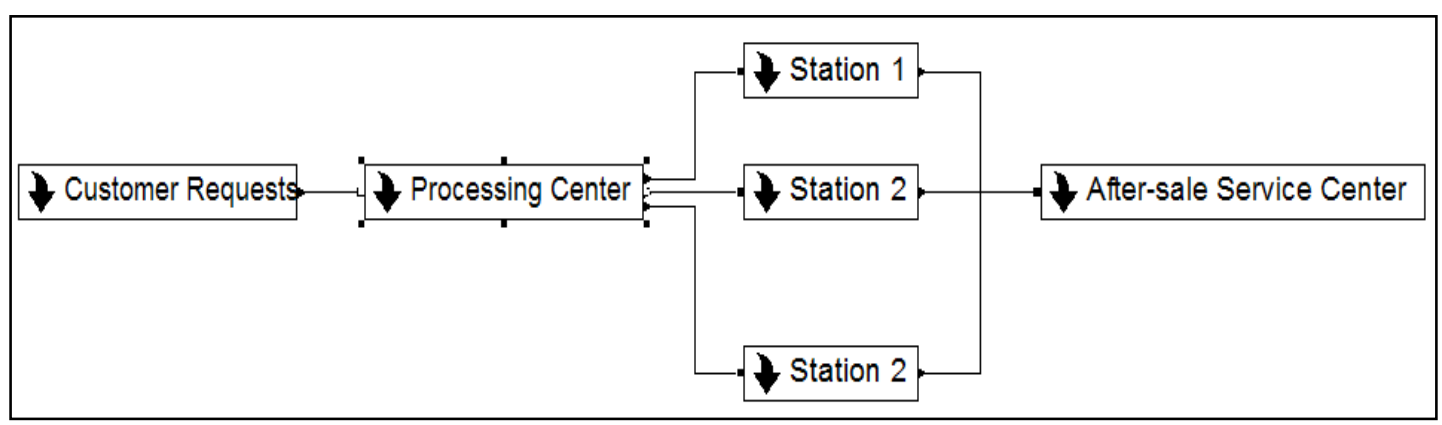

Figure 4. The simulation model of the mode-MSLS.

\begin{tabular}{lrrrr} 
Scheduled Utilization & Average & Half Wvith & $\begin{array}{r}\text { Minimum } \\
\text { Average }\end{array}$ & $\begin{array}{r}\text { Maximum } \\
\text { Average }\end{array}$ \\
\hline Resource 1 & 0.6580 & .17 & 0.5007 & 0.8724 \\
Resource 2 & 0.5581 & .13 & 0.4252 & 0.7138 \\
Resource 3 & 0.1249 & .06 & 0.04641785 & 0.1668 \\
Resource 4 & 0.3365 & .09 & 0.2646 & 0.4551
\end{tabular}

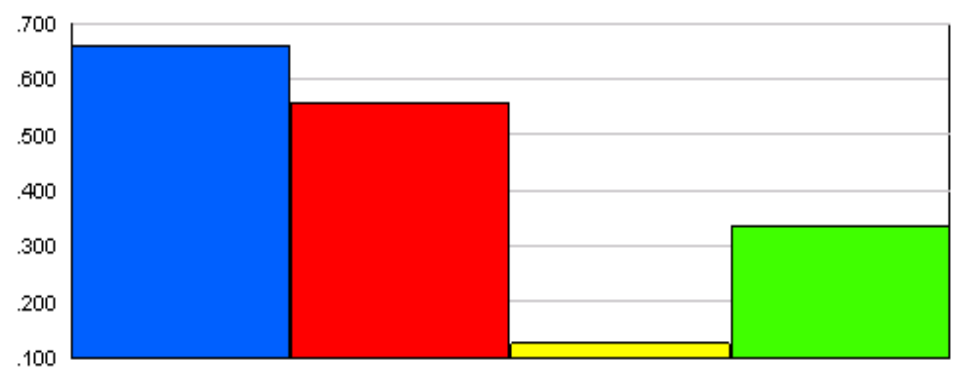

Figure 5. The average resource utilization of mode-MSLS.

TABLE II.

OUTPUT PERFORMANCE INDICATORS

\begin{tabular}{|c|c|}
\hline $\begin{array}{c}\text { Performance } \\
\text { indicators }\end{array}$ & $\begin{array}{c}\text { Mode- } \\
\text { MSLS }\end{array}$ \\
\hline $\begin{array}{c}\text { The average } \\
\text { waiting } \\
\text { time(hours) }\end{array}$ & 4.4674 \\
\hline $\begin{array}{c}\text { The average } \\
\text { sojourn } \\
\text { time(hours) }\end{array}$ & 13.499 \\
\hline WIP & 3.0439 \\
\hline
\end{tabular}

According to these output performance indicators of the average waiting time, the average sojourn time, and the WIP(the average of the queue length)the all kinds of performance indicators of mode- MSLS are feasible and workable.the M-commerce steel logistics system has the practical rationality to improve the development of Chinese steel logistics.

\section{DESIGN OF OPTIMIZING BLUEPRINT}

In order to optimize the mode- MSLS, and according to the above situation, the 4 groups of system optimization schemes have been established.

The parameter setting is based on mode-MSLS, which is changed by the processing time of module-Assign, moduleProcess and pass rate of the module-Decide.
The operations are as follows:

(1)The servicing time of Choose goods Process obeys the triangular distribution :TRIA(1,2,3), The other parameters keep invariant .

(2)The servicing time of Conform order Process obeys the triangular distribution :TRIA $(1,4,8)$, The other parameters keep invariant .

(3)The processing time of Delivery Process obeys the triangular distribution :TRIA(1,2,3), The processing time of Delivery Process obeys the triangular distribution:TRIA(1,2,3), The other parameters keep invariant .

(4)he servicing time of Handing Process obeys the triangular distribution :TRIA(1,4,8), The other parameters keep invariant .

Statistical analysis of example simulation: 


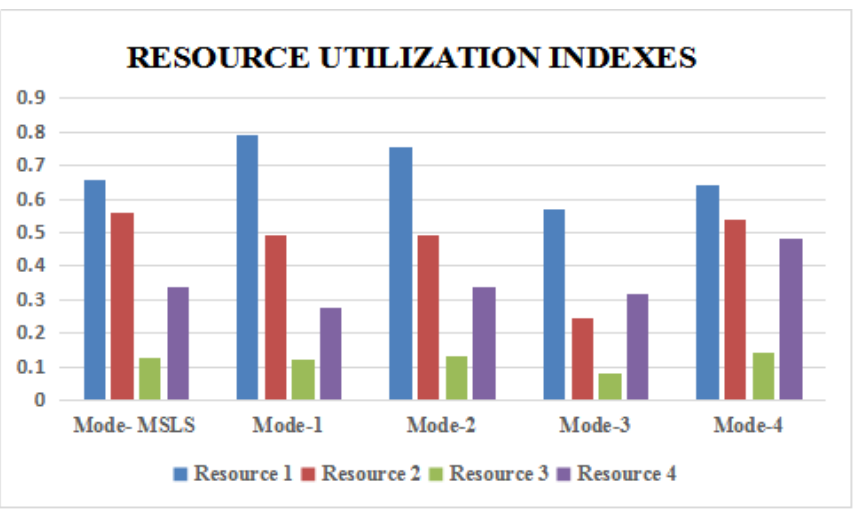

Figure 6. Comparison of mean resource utilization indexes of different models

TABLE III. PERFORMANCE INDICATORS COMPARISONS

\begin{tabular}{|c|c|c|c|c|c|}
\hline $\begin{array}{c}\text { Performa } \\
\text { nce } \\
\text { indicators }\end{array}$ & $\begin{array}{c}\text { Mode- } \\
\text { MSLS }\end{array}$ & $\begin{array}{c}\text { Mod } \\
\boldsymbol{e - 1}\end{array}$ & $\begin{array}{c}\text { Mode } \\
\mathbf{- 2}\end{array}$ & $\begin{array}{c}\text { Mode } \\
\mathbf{- 3}\end{array}$ & $\begin{array}{c}\text { Mode } \\
-\mathbf{4}\end{array}$ \\
\hline $\begin{array}{c}\text { The } \\
\text { average } \\
\begin{array}{c}\text { waiting } \\
\text { time(hour } \\
\text { s) }\end{array}\end{array}$ & $\begin{array}{c}4.467 \\
4\end{array}$ & $\begin{array}{c}5.486 \\
5\end{array}$ & $\begin{array}{c}5.656 \\
8\end{array}$ & $\begin{array}{c}1.826 \\
5\end{array}$ & $\begin{array}{c}4.880 \\
0\end{array}$ \\
\hline $\begin{array}{c}\text { The } \\
\text { average } \\
\text { sojourn } \\
\text { time(hour } \\
\text { s) }\end{array}$ & $\begin{array}{c}13.49 \\
9\end{array}$ & $\begin{array}{c}15.49 \\
19\end{array}$ & $\begin{array}{l}15.54 \\
24\end{array}$ & $\begin{array}{l}10.08 \\
90\end{array}$ & $\begin{array}{l}14.65 \\
71\end{array}$ \\
\hline WIP & $\begin{array}{c}3.043 \\
9\end{array}$ & $\begin{array}{c}3.122 \\
8\end{array}$ & $\begin{array}{c}3.351 \\
0\end{array}$ & $\begin{array}{c}1.805 \\
0\end{array}$ & $\begin{array}{c}3.250 \\
5\end{array}$ \\
\hline
\end{tabular}

By the results showed that:.the average resource1 utilization of the mode- 1 is $78.94 \%$ it will easily lead to the shortcomings of the system overloaded.But the average resource utilization of Mode- 4 is reasonable,the system is not showing the application unusually busy or system excessively idle.By comparison of performances of indications, it can be found that change the upper limit of exponential distribution, the Mode- 3 system and the mean sojourn time of the average waiting time is less than Mode1 and Mode-2, the queue is relatively short,more fast import entities, in other words ,the system in the process of customer waiting time and stay shorter queue is shorter, the processing efficiency is high,the speed of transport will be fast.

According to these output performance indicators of the average waiting time, the average sojourn time ,and the WIP(the average of the queue length)the all kinds of performance indicators of different modes, it can get an optimal result by changing the parameters of each stage of the process and changing the number of system resources.In short, this model can clearly express the requirements of the M-commerce Steel Logistics System, we can see the user transaction request, request processing, payment platform services, logistics and distribution of the logistics system. Changing the parameters that affect the user's service request arrival or the service time of each phase in the process can get different results.

\section{CONCLUSION}

The paper puts forward the planning method of steel logistics system under M-commerce environment,and establishing the logic simulation model, and use the Arena simulation software reflect the process of the logistics system veraciously.Combined with the realities of situation, and it raises the optimization schemes and then analyze the simulation result and give the conclusion and improving performances, though the research.We can find a scientific methods to put some suggestions for steel logistics and achieve the goals about the M-commerce steel logistics used in steel industries, and share those management methods to the steel enterprises.Finally,accelerating the development of M-commerce steel logistics system Therefore, future research will focus on deepening the simulation of knowledge learning and further understanding of the process of mobile e-commerce, it can make the simulation more accurate and more detailed, more accurately simulate the actual application process, to provide more reliable references and guidances.

\section{ACKNOWLEDGMENT}

This research was financially supported by the school of Management of Wuhan University of Science and Technology and Graduate Student Education Research Project of Wuhan University of Science and Technology.

\section{REFERENCES}

[1] LEI Dingyou, WANG Dong and LIIU Mingxiang, "Optimization Model and Algorithm of Utilization of Arrival and Departure Tracks in Railroad Passenger Station,"(in Chinese) Journal of Traffic and Transportation Engineering, vol. 7, pp. 84-87, October 2007.

[2] W. David Kelton, Randall P. Sadowsky and David T. Sturrock, "Simulation with Arena,"3rd ed.,New York: The McGraw-Hill Companies, 2004.

[3] R Shah,andM Makaryus,Simulation-Based Training for Pulmonary and Critical Care Fellows in Urgent Endotracheal Intubation: Does Skill Transfer to the Clinical Arena.,vol150(4),p.636A-636A, 2016.

[4] LI Jitao and FU Jia, "Microscopic Simulation Model and Analysis on Waiting Area of Large Scale Railway Passenger Station,"(in Chinese) Journal of Transportation Systems Engineering and Information Technology, vol. 11, pp. 44-49, February 2011.

[5] XU Yan, "Optimization of Application of the Waiting Hall of Railway Passenger Station,"(in Chinese) Railway Operation Technology, vol. 13, pp. 32-34, October 2007.

[6] YIN Hongjun and LUO Sai, "Study on Program Optimal Methods of Waiting Hall in Major Railway Passenger Station,"(in Chinese) Railway Computer Application, vol. 17, pp. 4-6, September 2008.

[7] James A. Fitzsimmons and Mona J. Fitzsimmons, (in Chinese) "Service management: operations, strategy and Information Technology, "Beijing: China Machine Press, 2003.

[8] Yinghui Tang and Xiaowo Tang. "Queuing Theory,"(in Chinese)Beijing:Science Press, 2006. 